\title{
DÜŞÜK HIZLI DARBE YÜKÜNE MARUZ KOMPOZİT PLAKALARA ASİDİK ORTAMIN ETKİSİ
}

\author{
Ümran ESENDEMIR ${ }^{1 *}$, Haluk KARACA ${ }^{2}$
}

${ }^{1}$ Süleyman Demirel Üniversitesi, Mühendislik Fakültesi, Makine Mühendisliği Bölümü, Isparta, Türkiye

${ }^{2}$ Süleyman Demirel Üniversitesi, Fen Bilimleri Enstitüsü, Makina Mühendisliği A.B.D., Isparta Türkiye

\begin{tabular}{|c|c|}
\hline Anahtar Kelimeler & Öz \\
\hline $\begin{array}{l}\text { Kompozit malzeme, } \\
\text { Asit çözeltisi, } \\
\text { Darbe davranışı, } \\
\text { Hasar, } \\
\text { Darbe enerjisi. }\end{array}$ & 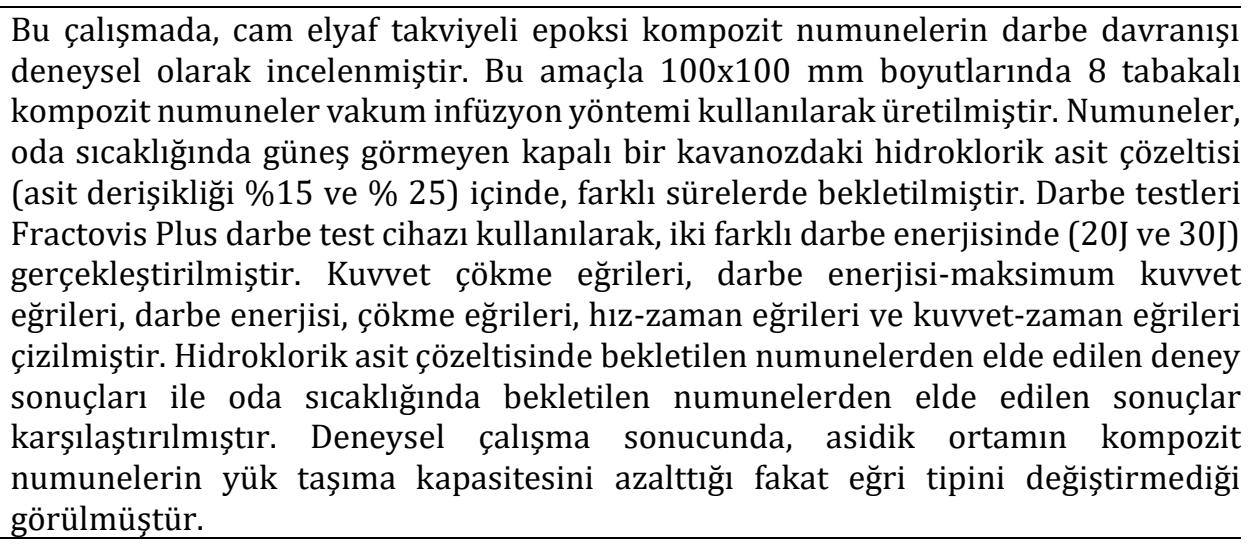 \\
\hline
\end{tabular}

\section{THE EFFECT OF ACIDIC ENVIRONMENT ON COMPOSITE PLATES SUBJECTED TO LOW \\ VELOCITY IMPACT}

\begin{tabular}{l}
\hline Keywords \\
\hline Composite material, \\
Acid solution, \\
Impact behavior, \\
Damage, \\
Impact energy.
\end{tabular}

\section{Keywords}

Acid solution

Impact behavior

Impact energy.

\begin{abstract}
In this study, impact behaviors of glass fiber/epoxy composite plates have been investigated, experimentally. For this purpose, composite samples have been manufactured in dimensions of $100 \times 100 \mathrm{~mm}$ and with layer of 8 . The specimens kept into hydrochloric acid solutions (acid concentration 15\% and 25\%) in a closed glass jar in sunless for different exposure times at room temperature. Impact tests were performed using Fractovis Plus impact test machine at two different impact energies (20J and 30J). After impact tests, force- deflection curves, impact energydeflection, velocity-time and force-time have been plotted. The experiments results obtained from the specimens kept into hydrochloric acid solutions were compared with no immersed specimens. As a result of experimental studies, it was seen the acidic environment reduced the load carrying capacity of composite specimens but did not change the curve type.
\end{abstract}

\section{Alıntı / Cite}

Esendemir, Ü., Karaca, H., (2019). Düşük Hızlı Darbe Yüküne Maruz Kompozit Plakalara Asidik Ortamın Etkisi, Mühendislik Bilimleri ve Tasarım Dergisi, 7(1), 26-33.

Yazar Kimliği / Author ID (ORCID Number)

Ü. Esendemir, 0000-0001-6947-9310

H. Karaca, 0000-0001-6097-6679

\begin{tabular}{|l|l|}
\hline Makale Süreci / Article Process \\
\hline Başvuru Tarihi / Submission Date & 06.03 .2018 \\
Revizyon Tarihi / Revision Date & 04.12 .2018 \\
Kabul Tarihi / Accepted Date & 19.12 .2018 \\
Yayım Tarihi / Published Date & 25.03 .2019 \\
\hline
\end{tabular}

\section{Giriş}

Birçok uygulama alanına sahip olan kompozit malzemeler kullanım yerlerine bağlı olarak çeşitli darbelere maruz kalabilmektedirler. Malzemede oluşan hasar, darbe enerjisine bağlı olarak değișmektedir. Kompozit malzemede darbe sonrası oluşan hasar türleri genellikle fiberlerin kırılması, matris çatlağı, fiber matris ara yüzey hasarı, delinme ve delaminasyon şeklindedir. Kompozit malzemelerin darbe davranışı birçok çalışmada incelenmiștir.

\footnotetext{
* ilgili yazar / Corresponding author: umranesendemir@sdu.edu.tr, +90-246-211-1233
} 
Aktaş vd. (2009), iki farklı tip cam/epoksi kompozitin farklı darbe enerjilerinde darbe testlerini yaparak kompozitlerde meydana gelen hasar modlarını belirlemişlerdir. Buna göre matris çatlağı ile başlayan hasar modunun, darbe enerjisinin artmasıyla birlikte cam elyafin gevrek yapısından dolayı fiber kırılmalarının baskın olduğu bir hasara dönüștüğünü bildirmişlerdir. Baucom ve Zikry (2005) cam elyaf takviyeli kompozit numuneler tekrarlı yapılan düşük hızlı darbe hasar durumunu incelemişler, elyafların belli darbe tekrarı sonrası uğradığı hasar üzerinde çalışmışlardır. Uyaner vd. (2007) düşük hızlı darbeye maruz E camı/epoksi tabakalı kompozitlerde plaka boyutlarının darbe davranıșına olan etkisini incelemişlerdir. Yapılan çalışmada $180 \times 50 \mathrm{~mm}$, 180x100 mm ve 180x150 mm boyutlarında levhalar kullanılmıștır. Numune genişliği büyüdükçe malzeme üzerindeki kalıcı yer değiştirme miktarının azaldığını belirtmişlerdir. Hosur vd. (2005) düşük hızlı darbe yüklerinde dört farklı hibrit laminadan olușan laminatların darbe davranışını dört farklı darbe enerjisi için deneysel olarak incelemişlerdir Fidan vd. (2011) cam fiber takviyeli polyester kompozitte tekrarlı düşük hızlı darbe testleri sonrası ortaya çıkan içyapı hasarlarını incelemişlerdir. Tekrarlı darbelerin malzeme içyapısında matris çatlağı, delaminasyon ve fiber kırılmaları olmak üzere üç farklı hasar oluştuğunu belirtmişlerdir. Berk vd. (2016) S2 cam elyaf epoksi ve aramid epoksi kompozit plakaların darbe davranışını iki farklı darbe enerjisi (20J ve 30J) için darbe davranışını deneysel ve nümerik olarak incelemişlerdir. 30J darbe enerjisi uygulanan S2 cam elyaf kompozit numunelerde geri sekme oluşurken aramid elyaf kompozitlerde delinme hasarının oluştuğu belirtilmiştir. Ayrıca nümerik ve deneysel sonuçların birbiriyle uyumlu olduğu görülmüștür. Dorigato ve Pegoretti (2014) carbon/bazalt hibrit kompozitlerin eğilme ve darbe davranışı üzerine bir çalışma yapmışlardır. Bazalt ve E-cam elyaf kumaşları karbon elyaf kumaşlarla birleştirilmiştir. Carpy darbe testleri yapılmıştır. Kompozitteki bazalt ve cam fiber içeriğinin artması, kompozitin darbe dayanımını artırmıştır. Naik vd. (2000) düşük hızlı darbeye maruz polimer matris örgü kompozitlerin hasarını incelediler. Plaka kalınlığı arttıkça darbe dayanımını arttığı belirtilmiștir. Stamenovic vd. (2011) cam elyaf takviyeli polyester kompozitlerin çekme dayanımına alkalin ve asit çözeltisinin etkisini incelemişlerdir. pH değeri azaldığı zaman çekme dayanımının arttığı belirtilmiştir. Ayrıca çekme dayanımını bekletme süresinin de etkili olduğu belirtilmiştir. Yılmaz ve Sınmazçelik (2010) pim bağlantılı cam fiber takviyeli polifenilen sülfit kompozitlerin yatak dayanımlarına asidik ortamın etkisini incelemişlerdir. 16 hafta asidik ortamda bekletildikten sonra yapılan deneylerde; ilk ve son hasar yüklerinde sırasıyla yaklaşık \%95 ve \%93 oranında azalma olduğu belirtilmiștir.

Kompozit malzemeler uçak, uzay, otomobil, gemi ve asit tankı gibi birçok kullanım potansiyeline sahiptir. Kompozitlerin korozyon dirençlerinin yüksek olması onların asitli koşullarda kullanılmasına imkân tanımaktadır. Tanklar ve borular, zararlı kimyasalların depolanmasında kullanıldıklarında asidik etki gösterebilir. Literatürde cam elyaf takviyeli epoksi kompozitlerin darbe davranışına farklı bekletme sürelerinde farklı asit derișikliklerinin etkisi üzerine çok fazla bir çalışmaya rastlanılmamıştır. $\mathrm{Bu}$ yüzden; bu çalışmada farklı derişiklerdeki HCL çözeltisi içinde farklı sürelerde bekletilen kompozit numunelerin darbe davranışı deneysel olarak incelenmiştir. Bu amaçla kuvvet çökme eğrileri, darbe enerjisi- maksimum kuvvet eğrileri, darbe enerjisi, çökme eğrileri, hız zaman eğrileri ve kuvvet zaman eğrileri çizilmiştir.

\section{Materyal ve Metot}

\subsection{Numune Üretim Parametreleri}

Deneysel çalışmada kullanılan 8 tabakalı [+45/$45 / 0 / 90]_{s}$ oryantasyon açısına sahip cam elyaf takviyeli epoksi kompozit plakaların üretimi Dokuz Eylül Üniversitesi Makine Mühendisliği Kompozit Üretim Laboratuvarında yapılmıștır. Fiber malzeme olarak E-cam $300 \mathrm{gr} / \mathrm{m}^{2}$ tek yönlü kumaş kullanılmıștır. Kullanılan fiber malzeme Metyx markadır. Reçine malzemesi olarak Huntsman Epoxy Resin XB 3585 ve sertleștirici olarak ise Hardener XB 3486 kullanılmıștır. Hacimsel olarak epoksi ve sertleștirici olarak 100 birim epoksiye 32 birim sertleștirici kullanılmıştır. Kompozit malzeme üretim yöntemi olarak vakum infüzyon yöntemi kullanılmıștır. Kürleme işlemi 5 saat boyunca $100{ }^{\circ} \mathrm{C}^{\prime}$ de yapılmıștır.

Üretimi yapılan plakaların kesimleri ve darbe testleri Dokuz Eylül Üniversitesi Makine Mühendisliği Mekanik Laboratuvarında yapılmıștır.

\subsection{Darbe Testleri}

Darbe testleri Fractovis Plus darbe test cihazında yapılmıştır. Şekil 1'de test cihazı ve test numunesinin test cihazına yerleştirilmesi gösterilmiştir. Test cihazı, serbest ağırlık düşürme prensibine göre çalışan yer tipi, yüksek hızlı ve sistem kontrollü bir darbe cihazıdır. İmpuls sinyal şartlandırma birimine, impuls veri toplama kartına ve veri elde etme yazılımına sahip olması cihazı sistem kontrollü olma özelliği sağlamaktadır. Ayrıca test cihazı; numune üzerine düşürülen ağırlı̆̆ın, yükseklik, hız ve enerji gibi parametrelerin kontrollü olarak değiștirilebilmesine imkân vermektedir. Testler sırasında kullanılan vurucu kütlesi $4.926 \mathrm{~kg}$ olup, vurucunun ucu yarım küre şeklinde ve $12,7 \mathrm{~mm}$ çapa sahiptir. Deneyler oda sıcaklığında $\left(20^{\circ} \mathrm{C}\right)$ gerçekleştirilmiştir. Vurucunun numunelere çarpma hızı 20J için $2.85 \mathrm{~m} / \mathrm{s} ; 30 \mathrm{~J}$ için $3.49 \mathrm{~m} / \mathrm{s}^{\prime}$ dir. 


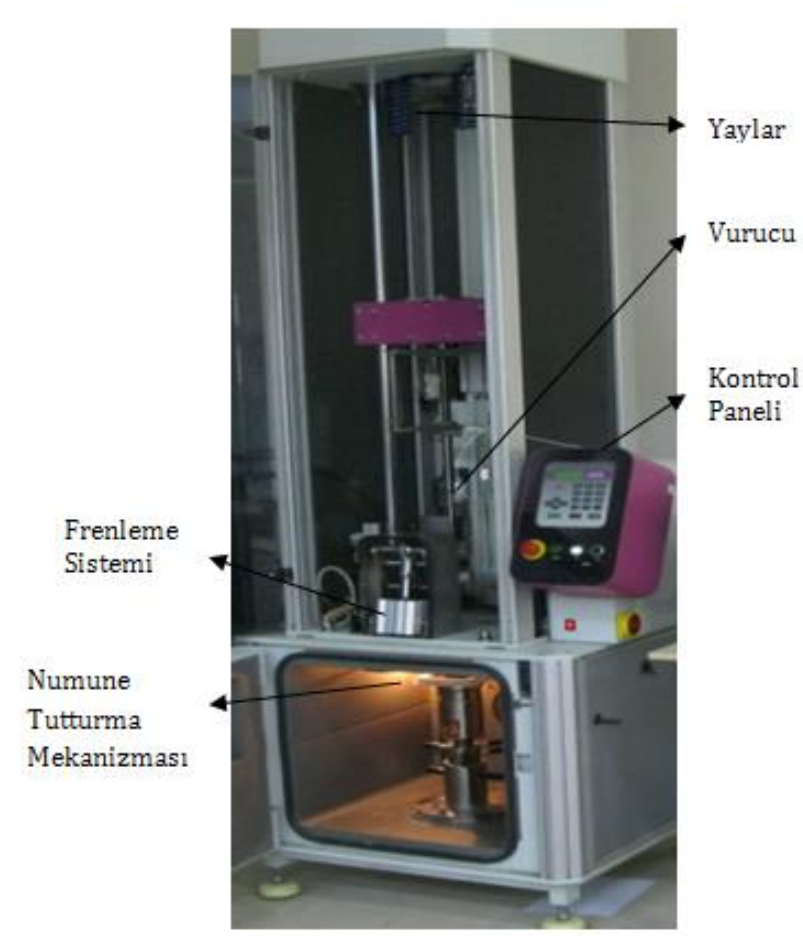

Şekil 1. Darbe test cihazı

\subsection{Deney Numunelerin Hazırlanması}

Deney asit çözeltileri (Şekil 2 ) hazırlandıktan sonra kompozit plakaların asidik ortamda bekletilme süresine göre kodlaması Tablo 1'de verilmiştir.
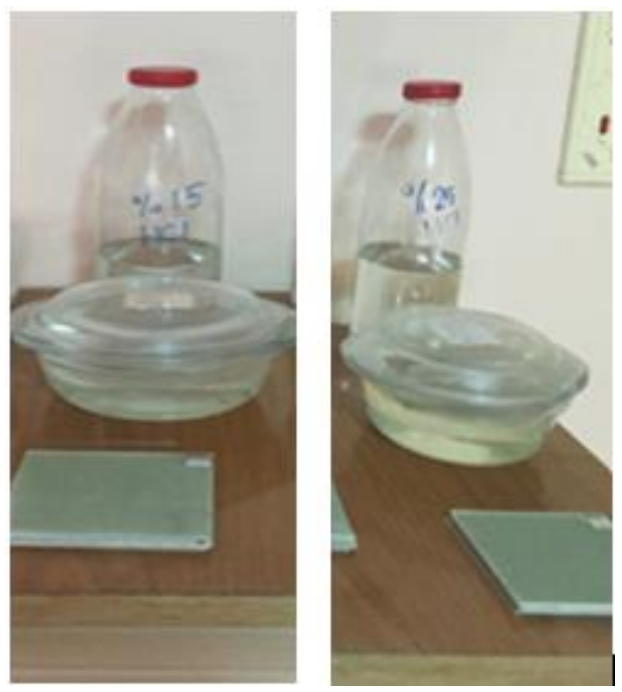

Şekil 2. Asidik derişikliklerine göre deney numunelerinin fotoğrafları

$\mathrm{Bu}$ çalışmada asidik derişikliği ve bekletme süreleri literatür çalışmaları esas alınarak seçilmiştir. Yılmaz ve Sınmazçelik (2010) asidik ortamın pim bağlantılı cam elyaf takviyeli polifenilen sülfit kompozitlerin yatak dayanımlarına etkisini incelemişlerdir. Deney numunelerini asit çözeltisinde (\%37 hidroklorik asit$\% 67$ saf su), farklı sürelerde (1-2-3-4-6-12-16 hafta) bekletmişlerdir. Yapılan deney sonucunda 16 hafta asidik ortamda bekletilen numunelerin yatak dayanımlarının yaklaşık \%95 azaldığını belirtmişlerdir. Başka bir çalışmada ise Mortas vd. (2014) hidroklorik asit $(\% 5,15,25,35$ HCL) içinde bekletilen kevlar/epoksi ve karbon/epoksi kompozitlerin darbe davranışlarını incelemişlerdir.

Tablo 1. Kompozit Malzemlerin Deney Türlerine Göre Kodlanması

\begin{tabular}{|c|c|c|c|}
\hline & $\begin{array}{c}\text { Asidik } \\
\text { Derişikliği }\end{array}$ & $\begin{array}{c}\text { Bekletilme } \\
\text { Süresi } \\
\text { (gün) }\end{array}$ & $\begin{array}{c}\text { Joule } \\
\text { Miktarı }\end{array}$ \\
\hline K200 & $\% 0$ & - & $20 \mathrm{~J}$ \\
\hline $\mathrm{K} 201$ & $\% 15$ & 15 & $20 \mathrm{~J}$ \\
\hline $\mathrm{K} 202$ & $\% 25$ & 60 & $20 \mathrm{~J}$ \\
\hline $\mathrm{K} 300$ & $\% 0$ & - & $30 \mathrm{~J}$ \\
\hline $\mathrm{K} 301$ & $\% 15$ & 45 & $30 \mathrm{~J}$ \\
\hline $\mathrm{K} 302$ & $\% 25$ & 15 & $30 \mathrm{~J}$ \\
\hline
\end{tabular}

\section{Araştırma Bulguları}

Şekil 3-5'te 20J darbe enerjisi uygulanan numunelerin darbe sonrası fotoğrafı ve kuvvet-çökme eğrileri verilmiştir (Karaca, 2018).

Şekil 3-5 den görüleceği üzere darbe uygulanan yüzeyden alınan fotoğraf görüntülerinde delaminasyonlar, matris çatlağı ve çok az sayıda fiber kırılmalar görülmektedir. Oda sıcaklığında bekletilen K200 kodlu numunede (Șekil 3) hasar sadece darbenin uygulandığı bölgede görülürken, asitli ortamda bekletilen K201 ve K202 kodlu numunelerde (Şekil4-5) hasar orta eksen boyunca dağılmıştır. K200, K201 ve K202 numunelerinin kuvvet-çökme eğrileri kapalı eğridir. Eğrinin kapalı olması vurucunun kompozit numune yüzeyinden geri sekme yaptığının ve numunenin daha az hasara uğradığının bir göstergesidir.

Şekil 6-8' de 30J darbe enerjisi uygulanan numunelerin darbe sonrası fotoğrafı ve kuvvet-çökme eğrileri verilmiştir (Karaca, 2018).

(2013a) hidroklorilik asit (HCL) ve sodyumhidroksit $(\mathrm{NaOH})$ içinde bekletilen cam fiber takviyeli epoksi kompozitlerin eğilme dayanımlarını incelemişlerdir. Çalışma sonucunda $\mathrm{NaOH}$ çözeltisinin HCL çözeltisine göre kompozit numunelerin dayanımını daha çok azalttığını belirtmişlerdir. Ayrıca, kompozit numunenin eğilme özelliklerinde gözlenen azalmayı fiber-matris ara yüzeyindeki bozulmaya ve matrisin elastisite modülüne bağlamışlardır. K300, K301 ve K302 numunelerinin kuvvet-çökme eğrileri açık eğridir. Ĕ̆rinin açık eğri olması numunelerin daha çok hasara uğradığının bir göstergesidir. 
Şekil 6-8'den görüleceği üzere darbe uygulanan yüzeyden alınan fotoğraf görüntülerinde

kodlu numunede (Şekil 6) hasar sadece darbenin uygulandığı bölgede fiber kırılmaları delinme hasarları görülürken, asitli ortamda bekletilen K301 ve K302 kodlu numunelerde (Şekil 7-8) ise bir hat boyunca lif ve matris malzemesinin ayrildı̆̆ görülmüştür. Asidik ortamın kompozit malzemeyi gevrekleștirdiğini, enerji absorbe etme özelliğini ve eğilme dayanımını azalttığını söyleyebiliriz. Amora vd. (2013a) hidroklorilik asit (HCL) ve sodyumhidroksit $(\mathrm{NaOH})$ içinde bekletilen cam fiber takviyeli epoksi kompozitlerin eğilme dayanımlarını incelemişlerdir.

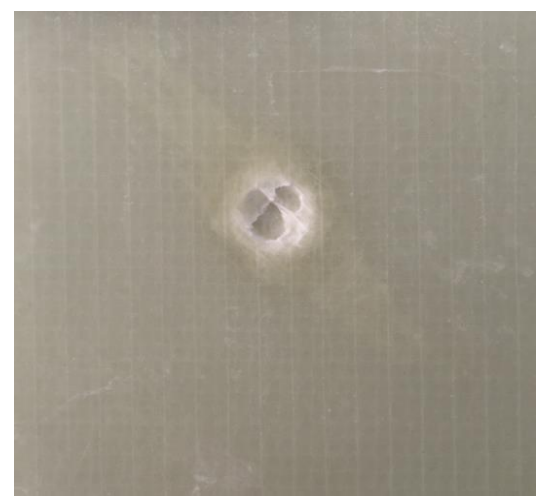

delaminasyonlar, delinme, fiber kırılmaları görülmektedir. Oda sıcaklığında bekletilen K300

Çalışma sonucunda NaOH çözeltisinin HCL çözeltisine göre kompozit numunelerin dayanımını daha çok azalttığını belirtmişlerdir. Ayrıca, kompozit numunenin eğilme özelliklerinde gözlenen azalmayı fiber-matris ara yüzeyindeki bozulmaya ve matrisin elastisite modülüne bağlamıșlardır. K300, K301 ve K302 numunelerinin kuvvet-çökme eğrileri açık eğridir. Ĕgrinin açık eğri olması numunelerin daha çok hasara uğradığının bir göstergesidir.

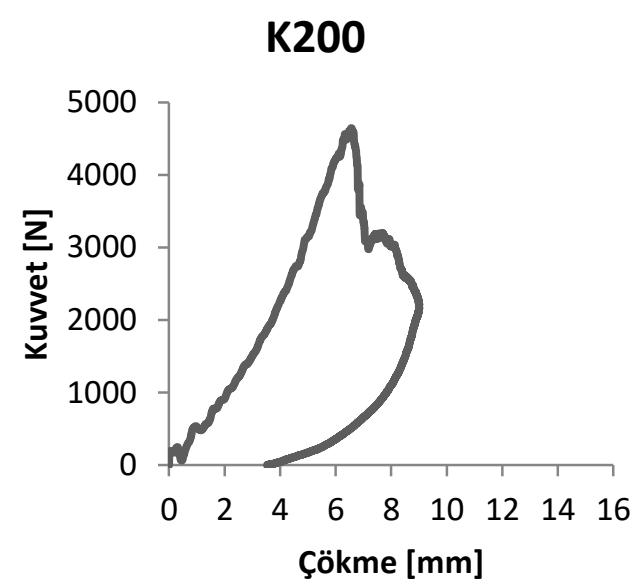

Şekil 3. 20J darbe enerjisi uygulanan K200 numunesinin darbe sonrası fotoğrafı ve kuvvet-çökme eğrisi

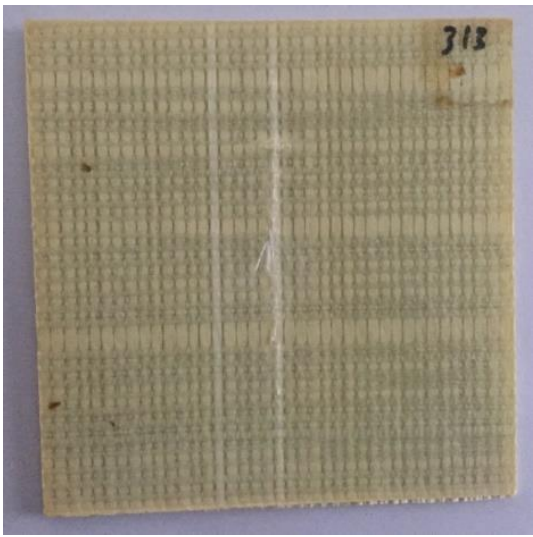

K201

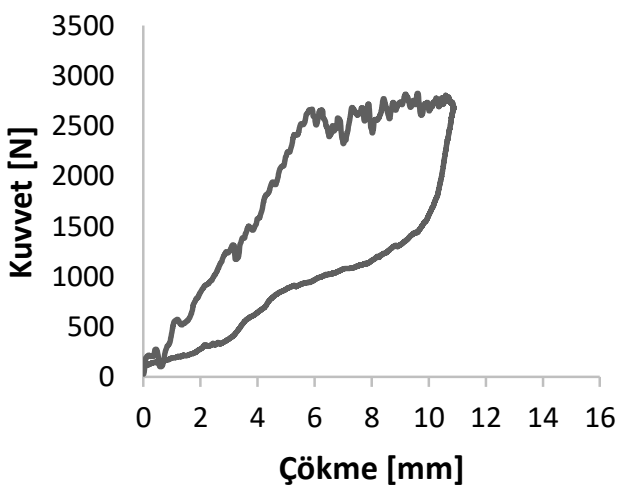

Şekil 4. 20J darbe enerjisi uygulanan K201 numunesinin darbe sonrası fotoğrafı ve kuvvet-çökme eğrisi 

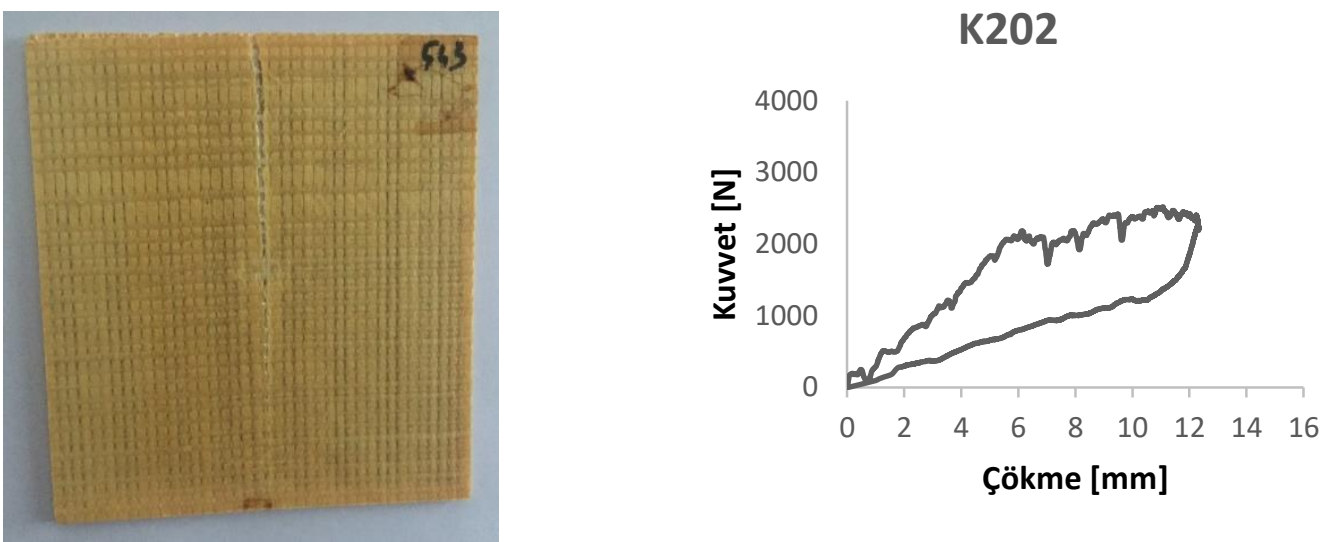

Şekil 5. 20J darbe enerjisi uygulanan K202 numunesinin darbe sonrası fotoğrafı ve kuvvet-çökme eğrisi
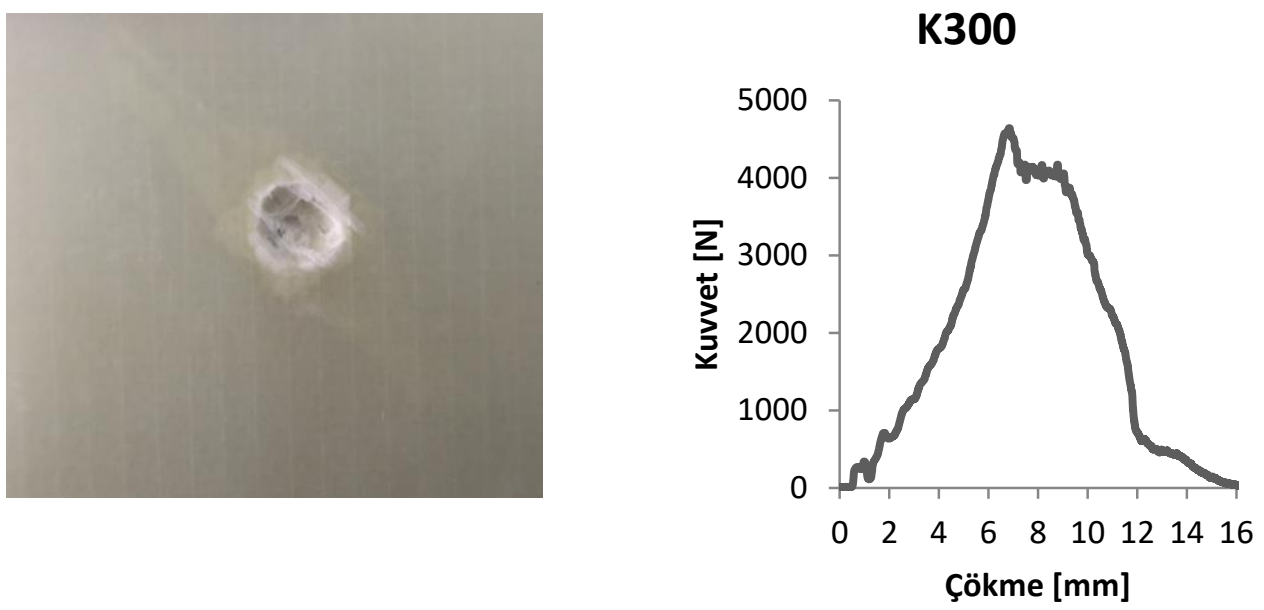

Şekil 6. 30J darbe enerjisi uygulanan K300 numunesinin darbe sonrası fotoğrafı ve kuvvet-çökme eğrisi

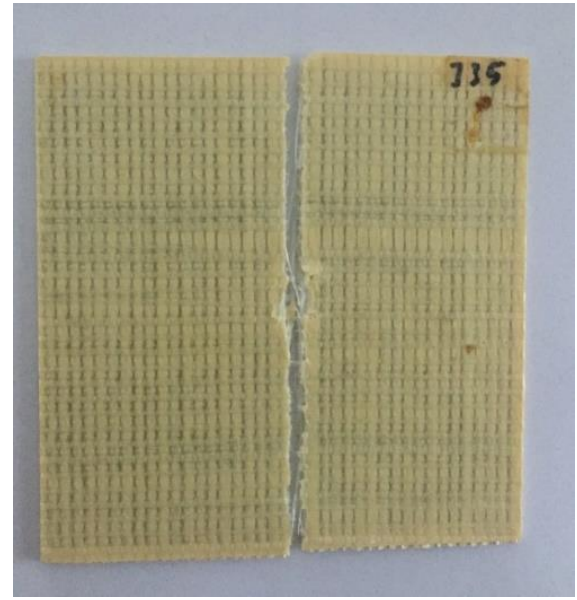

K301

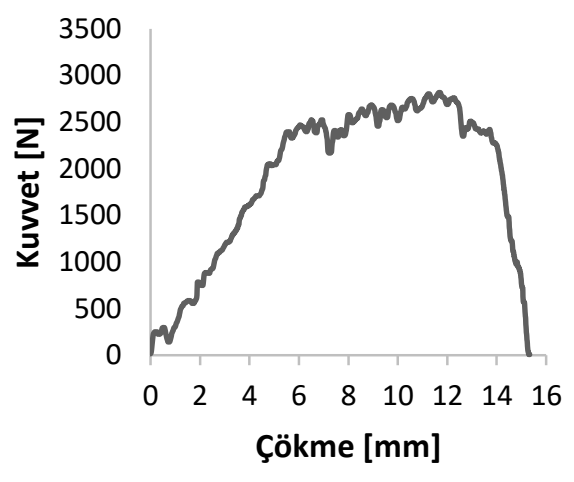

Şekil 7. 30J darbe enerjisi uygulanan K301 numunesinin darbe sonrası fotoğrafı ve kuvvet-çökme eğrisi

Şekil 9'da farklı süre ve farklı asit derişikliklerinde bekletilen numunelerin kuvvet-çökme eğrisi verilmiştir.

Şekil 9'da verilen numunelerin kuvvet-çökme eğrileri karşılaştırıldığında aynı darbe enerjisine maruz kalan numunelerin aynı darbe davranışı sergilediği görülmüștür. K200, K201 ve K202 numunelerinin kuvvet-çökme eğrileri 20 J'de kapalı eğri iken K300,
K301 ve K302 numunelerde 30 J'de açık eğridir. Kapalı eğri görülen numunelerde geri sekme oluşurken açık eğri görülen numunelerde delinme meydana gelmiştir. Elde edilen sonuçlar literatürle uyum içindedir. Mortas vd. (2014) hidroklorik asit $(\% 5,15,25,35 \mathrm{HCL})$ ve sodyum klorür $(\% 5,15,25,35$ $\mathrm{NaOH}$ ) içinde bekletilen kevlar/epoksi ve karbon/epoksi kompozitlerin darbe davranıșlarını incelemişlerdir. Yapılan çalışmada \%15 ve \%35 HCL 
asit çözeltisinde ve oda sıcaklığında bekletilen numunelerin kuvvet-çökme eğrisi çizilmiştir. Eğrilerden asidik ortamın numunenin yük taşıma kapasitesini azalttığı fakat eğri tipinin değiştirmediği görülmüştür. Şekil 10'da farklı asit derişiklerinde farklı sürelerde bekletilen kompozitlerin darbe enerjisine karşı maksimum çökme ve maksimum kuvvet değerleri verilmiştir.

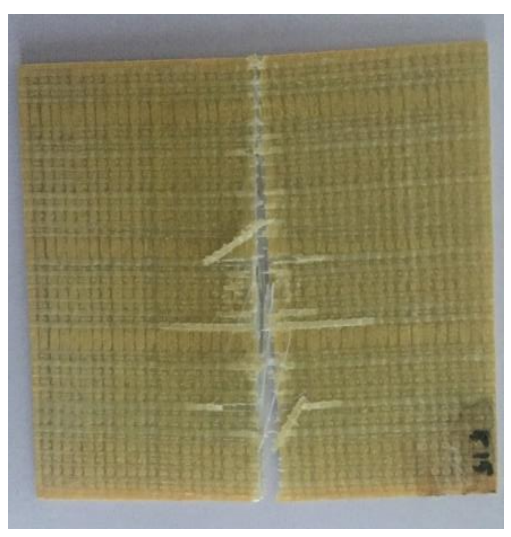

\section{K302}

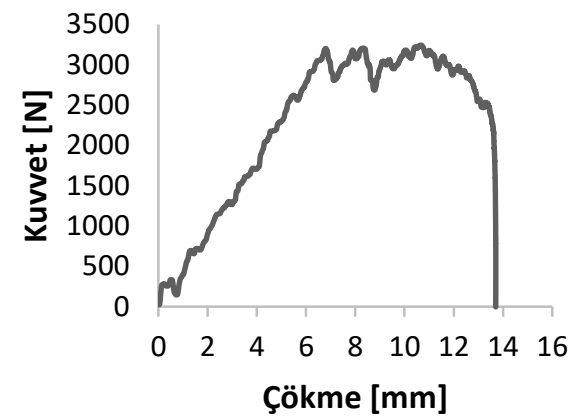

Şekil 8. 30J darbe enerjisi uygulanan K302 numunesinin darbe sonrası fotoğrafı ve kuvvet-çökme eğrisi
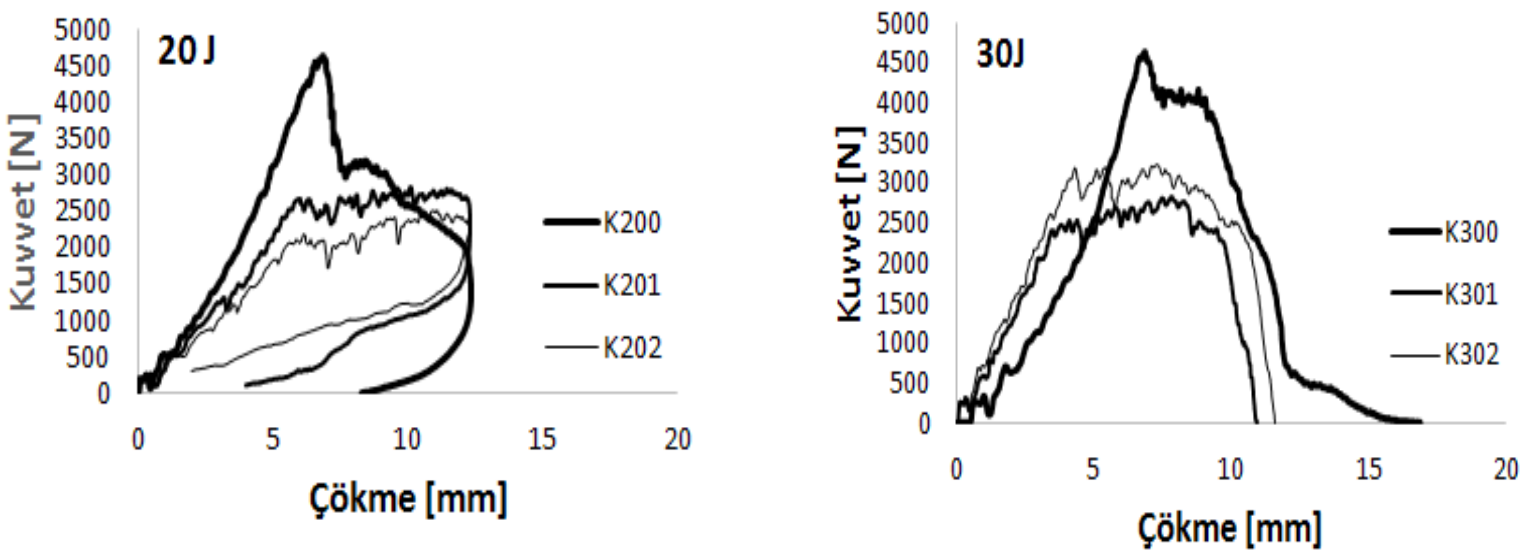

Şekil 9. Farklı asit derişiklerinde bekletilen numunelerin kuvvet-çökme eğrileri
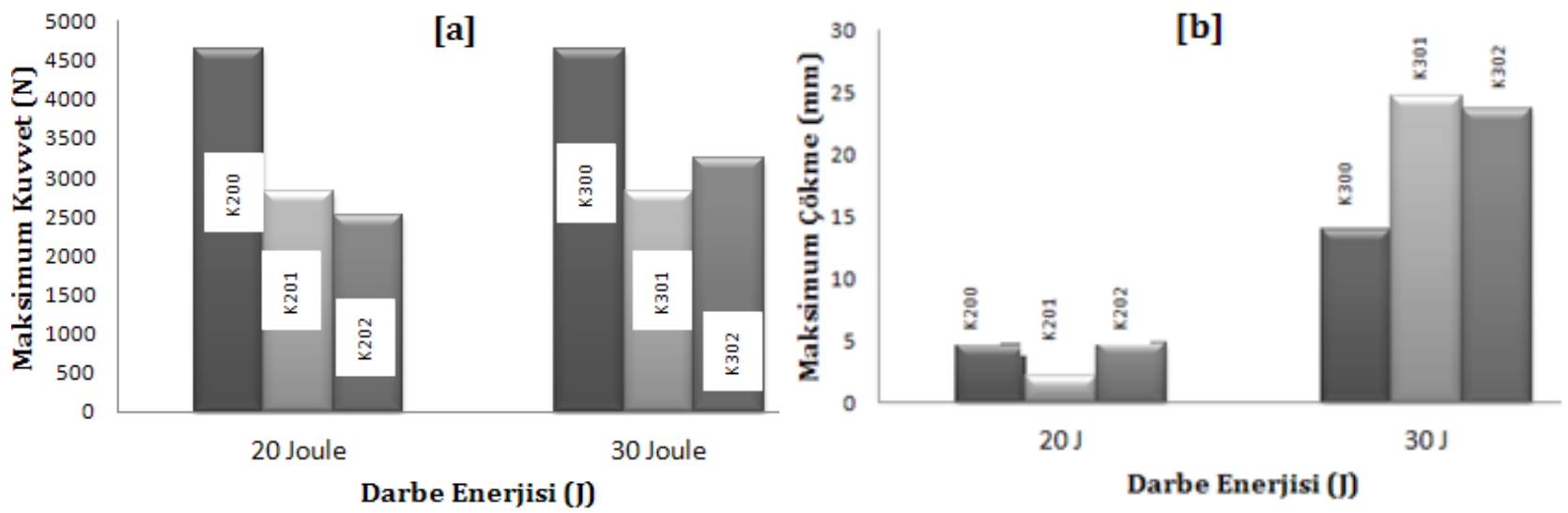

Şekil 10. Farklı asit derişiklerinde bekletilen numunelerin farklı iki darbe enerjisine karşı (a) maksimum kuvvet, (b) maksimum çökme değerleri

Şekil 10 (a)'dan görüleceği üzere asidik ortam, numunelerin yük taşıma kapasitesini azaltmıştır. K201 numunesi K202 numunesine göre daha düşük asit derişikliğinde daha az sürede bekletildiğinden yük taşıma kapasitesi daha büyüktür. 30J darbe enerjisi altında K302 numunesi K301 numunesine göre daha yüksek asit derişikliğinde, daha kısa sürede bekletilmiştir. Şekilden görüleceği üzere daha fazla sürede daha düşük asit derişikliğininde bekletilen K301 numunesinin yük taşıma kapasitesi daha düşüktür. Buradan numunelerin daha uzun sürede asidik ortamda bekletilmesinin kompozit numunenin 
dayanımını daha çok etkileğini söyleyebiliriz. Mahmoud ve Tantawi (2003) eğilme dayanımı, sertlik ve Charpy darbe direnci üzerine bekletilme süresinin etkisini incelemişlerdir. 60 ve 90 gün HCL çözeltisinde bekletilen numunelerin Charpy darbe dirençlerini sırasıyla yaklaşık $\% 5$ ve $\% 10$ oranında azalma olduğunu belirtmişlerdir. Amora vd. (2013b) cam/epoksi kompozit plakanın darbe dirençlerini, korozif ortamın ve bekletme süresinin düşürdüğünü belirtmiștir. Tüm ortamlar için darbe enerjisi arttıkça çökme miktarı artmaktadır (Şekil 10 (b)). 20J için K202 numunenin, 30J için K301 numunesinin çökme değerleri daha büyük değerdedir. Bu sonuçlar mevcut literatürle uyum içindedir. Mathivanan ve Jerald (2010), düşük darbe hızlarında farklı enerji seviyelerinde örgü cam fiber takviyeli epoksi kompozit malzemenin darbe davranışını deneysel olarak incelemişlerdir. Kompozit numunelere 3.14J, 4.71J, 6.28J, 7.8J ve 15.7J enerji seviyelerinde darbe uygulanmış ve darbe enerjisi attıkça kompozit numunenin hasarının arttığı belirtilmiştir.

Numunelerin daha uzun sürelerde bekletilmesi çökme değerini artırmaktadır. Numunelerin çökme değerlerini asit derişiklerinden ziyade bekletilme süreleri daha çok etkilemektedir.

20J ve 30J darbe enerjilerinde test edilen farklı süre ve asit derişiklerinde bekletilen numunelere ait kuvvetzaman eğrileri Şekil 11'de verilmiştir. Şekil 11'den görüleceği üzere kuvvet eğrileri parabolik bir eğri şeklindedir. Darbe enerjisinin artmasıyla numuneye etkiyen kuvvet de artmaktadır. $\mathrm{Bu}$ artış oda sıcaklığında bekletilen numunelerde daha fazladır.

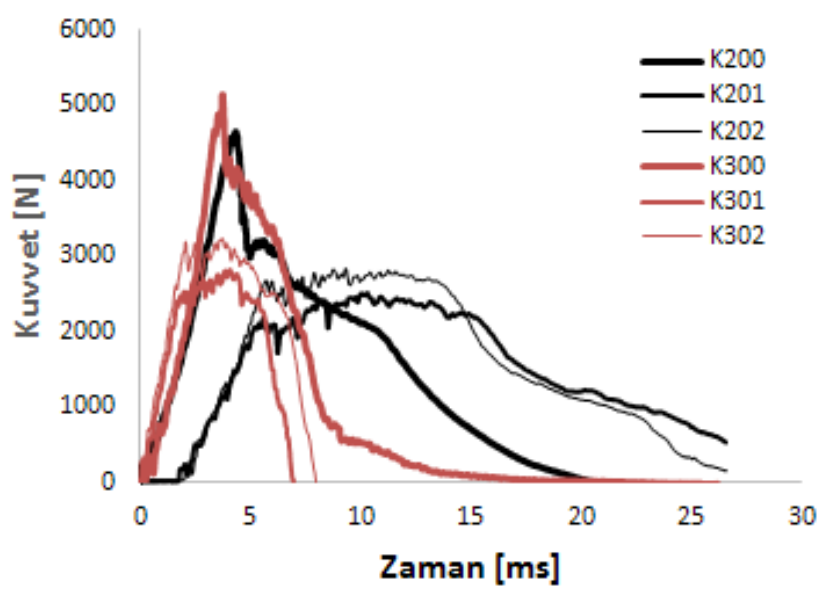

Şekil 11. 20J ve 30J darbe enerjileri altında farklı asit derişiklerinde farklı sürelerde bekletilen numunelerin kuvvet -zaman eğrileri

20J ve 30J darbe enerjilerinde test edilen farklı asit derişiklerinde farklı sürelerde bekletilen numunelere ait hız-zaman eğrileri Şekil 12'de verilmiştir.

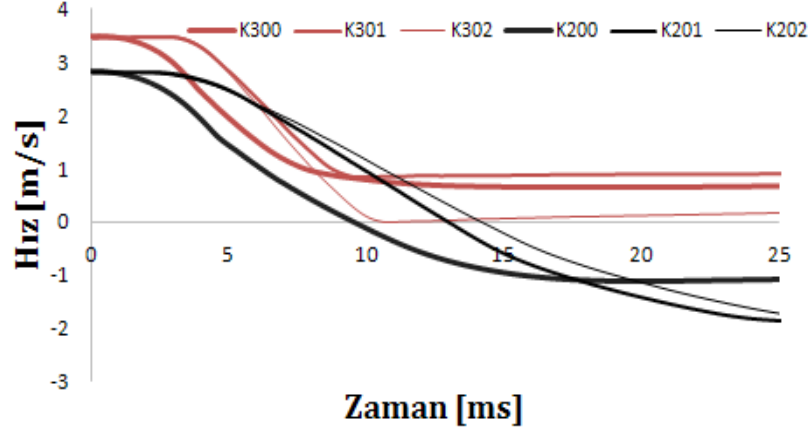

Şekil 12. 20J ve 30J darbe enerjilerinde farklı asit derişiklerinde farklı sürelerde bekletilen numuneler üzerinde gerçekleştirilen çarpma testleri için hızzaman eğrileri

Şekil 12'den görüleceği üzere 30J darbe enerjisi için K300, K301 ve K302 numunelerinde delinme meydana gelmiştir. Bu delinme olayında vurucu, belirli bir hızla numuneye saplanmıştır. Sürtünmeden dolayı numune kalınlığı boyunca hız yavaşlamıştır. Geri sekme olmadığı için eğriler pozitif bölgededir. K200, K201 ve K202 numunelerde vurucunun numune ile temasindan sonra hızında azalma ve geri sekme olmuştur. Bu geri sekme esnasında vurucunun hızı çarpma yönüne ters olduğu için eğriler negatif bölgeye geçmektedir.

\section{Sonuç ve Tartışma}

$\mathrm{Bu}$ çalışmada, cam elyaf takviyeli epoksi kompozit plakaların darbe davranışına asidik ortamın etkisi incelenmiştir. Yapılan deneysel çalışma sonucunda aşağıdaki sonuçlara ulaşılmıştır:

- Darbe enerjisinin artması fiber kırılmalarına ve ayrılmalarına sebep olmaktadır.

- Düşük darbe enerjisinde, matris çatlağı ve delaminasyon ana hasar modlarıdır.

- Tüm ortamlar için darbe enerjisi artıkça maksimum kuvvet ve çökme miktarı artmaktadır.

- Numuneler; farklı sürelerde, farklı deşikliklerindeki HCL çözeltilerinde bekletildikten sonra aynı darbe enerjilerine maruz bırakılmıştır. Darbeye maruz kalan bu numunelerin yük taşıma kapasitelerinde değişik oranlarda azalma görülmüștür. 20J darbe enerjisi altında oda sıcaklığında bekletilen K201 ve K202 numunelerin, K200 numunesine göre yük taşıma kapasitelerinde sırasıyla \%39 ve \%46 oranlarında azalma görülürken, 30J darbe enerjisi altındaki K301 ve K302 numunelerin de ise sirasiyla \%45 ve \%37 oranlarında azalma görülmüştür.

Numuneler; farklı sürelerde, farklı derişiklerdeki HCL çözeltilerinde bekletildikten sonra, aynı darbe enerjilerine maruz bırakılmışlardır. Darbeye maruz bırakılan bu numunelerin maksimum çökme değerlerinde genel olarak artış görülmüștür. 30J darbe enerjisi altında oda sıcaklığında bekletilen K301 ve K302 numunelerinin K300 numunesine göre çökme 
miktarlarında sırasıyla yaklaşık $\% 77$ ve \%60 oranında artış görülmüștür.

\section{Teşekkür}

Deneyleri yapmamızda yardımcı olan Dokuz Eylül Üniversitesi Makine Mühendisliği Bölümüne teşekkürlerimizi sunarı.

\section{Conflict of Interest / Çıkar Çatışması}

Yazarlar tarafından herhangi bir çıkar çatışması beyan edilmemiştir.

No conflict of interest was declared by the authors.

\section{Kaynaklar}

Aktaș, M., Ataș, C., İçten, B.M., Karakuzu, R., 2009. An Experimental Investigation of the Impact Response of Composite Laminates. Composite Structures, 87, 307-313.

Amaro AM, Reis PNB, Neto MA, Louro C. 2013a. Effects of Alkaline and Acid Solutions on Glass/Epoxy Composites. Polymer Degradation and Stability, 98, 853-862.

Amaro AM, Reis PNB, Neto MA, Louro C. 2013b. Effect of Different Acid Solutions on Glass/Epoxy Composites. Journal of Reinforced Plastics and Composites, 32(14), 1018-1029.

Baucom, J.N., Zikry, M.A. 2005. Low Velocity Impact Damage Progression in Woven E-Glass Composite Systems. Composites, 36, 658-664.

Berk, B., Karakuzu, R., İçten, BM., Arıkan, V., Arman, Y., Atas, $C$ ve Gören, A., 2016. An Experimental and Numerical Investigation on Low Velocity Impact Behavior of Composite Plates, Journal of Composite Materials, 50(25), 3551-3559.

Dorigato, A., Pegoretti, A., 2014. Flexural and Impact Behaviour of Carbon/Basalt Fibers Hybrid Laminates, Journal of Composite Materials, 48(9), 1121-1130.

Fidan, S., Avcu, E., Sinmazçelik, T. 2011. Cam Fiber Takviyeli Polyester Kompozitte Tekrarlı Darbe Yüklemeleriyle Oluşan Hasar Mekanizmaları, I. Ulusal Ege Kompozit Malzemeler Sempozyumu, 17-19 Kasım, İzmir, 1-12.

Hosur, M.V., Adbullah, M., Jeelani, S., 2005. Studies on the Low-Velocity Impact Response of Woven Hybrid Composites, Composite Structures, 67, 253262.

Karaca, H., 2018. Kompozit Malzemelerin Darbe Davranıșına Asidik Ortamın Etkisi ve Taguchi Metoduyla Analizi, Süleyman Demirel Üniversitesi,
Fen Bilimleri Enstitüsü, Yüksek Lisans Tezi, 86s, Isparta.

Mahmoud KM.,Tantaw SH, 2003. Effect of Strong Acids on Mechanical Properties of Glass/Polyester GRP Pipe at Normal and High Temperatures, PolymerPlastics Technology and Engineering, 42(4), 677 688.

Mathivanan, N.R., Jerald, J. 2010. Experimantal Investigation of Woven E-Glass Composite Laminates Subjected to Low-Velocity Impact at Different Energy Levels, Journal of Minerals \& Materials Characterization \& Engineering, 9(7): 643-652.

Mortas, N., Er, O., Reis, PNB, Ferreira, JAM, 2014. Effect of Corrosive Solutions on Composites Laminates Subjected to Low Velocity Impact Loading, Composite Structures, 108, 205-211.

Naik, N.K., Meduri, S., Sekher, Y. C. 2000. Polymer Matrix Woven Fabric Composites Subjected to Low Velocity Impact: Part II-Effect of Plate Thickness, Journal of Reinforced Plastics and Composites, 19 (13), 1031-1055.

Reis, PNB., Neto, MA., Amaro, AM., 2018. Effect of the Extreme Conditions on the Tensile Impact Strength of GFRP Composites, Composite Structures, 188, 48-54.

Yılmaz, T., Sınmazçelik , T., 2010. Experimental Investigation of Acid Environment Influences on Load-Bearing Performance of Pin-Connected Continuous Glass-Fiber-Reinforced Polyphenylenesulfide Composites, Polymer Composites, 31, 1-9.

Stamenovic M, Putic S, Rakin M, Medjo B, Cikara D. , 2011. Effect of Alkaline and Acid Solutions on the Tensile Properties of Glass-Polyester Pipes. Materials and Design, 32, 2456-2461.

Uyaner, M., Kara, M., Ataberk, N. 2007. E Camı/Epoksi Tabakalı Kompozitlerin Düșük Hızlı Darbe Davranıșına Numune Boyutlarının Etkisi, 8. Uluslararası Kırılma Konferansı Bildiriler Kitabı, , 7-9 Kasım, İstanbul, 361-368. 